\title{
Pengungkapan Corporate Social Responsibility, Struktur Corporate Governance dan Nilai Perusahaan
}

\author{
Salmah Pattisahusiwa ${ }^{1}$, Ferry Diyanti ${ }^{2}$ \\ Fakultas Ekonomi dan Bisnis Universitas Mulawarman
}

\begin{abstract}
The concept of the corporate social responsibility has a significant interest in Indonesia because believed to increase corporate's value for shareholders. This study aims to find the effect of corporate social responsibility disclosure and corporate governance structure on corporate value. The data were taken from annual report of mining companies listed in Indonesian Stock Exchange for period of 20142015. The sample collection has been done by using purposive sampling with the certain criteria so that 18 companies which meet criteria have been obtained as samples. Multiple Regression analysis was employed to analyze data. The result of this research show that corporate social responsibility disclosure and corporate governance structure have significant effect to thecorporate value.
\end{abstract}

Keyword: Corporate Social Responsibiliy Disclosure; Corporate Governance Structure; Corporate Value

\begin{abstract}
Abstrak
Konsep corporate social responsibility saat ini merupakan isu penting bagi perusahaan karena diyakini dapat meningkatkan nilai perusahaan. Penelitian ini bertujuan untuk mengetahui pengaruh dari pengungkapan corporate social responsibility dan struktur corporate governance terhadap nilai perusahaan. Pengambilan data diperoleh dari laporan tahunan perusahaan pertambangan yang terdaftar di Bursa Efek Indonesia selama tahun 2014-2015. Pengumpulan sampel dilakukan dengan menggunakan metode purposive sampling sehingga diperoleh diperoleh sampel sebanyak 18 perusahaan sesuai dengan kriteria yang telah ditetapkan. Analisis data dilakukan dengan menggunakan analisis regresi linier berganda. Hasil penelitian ini menunjukkan bahwa pengungkapan corporate social responsibility dan struktur corporate governance berpengaruh signifikan terhadap nilai perusahaan.
\end{abstract}

Kata Kunci: Pengungkapan Corporate Social Responsibility; Struktur Corporate Governance; Nilai Perusahaan

\author{
Permalink/DOI : http://dx.doi.org/10.21067/jem.v13i1.1763 \\ Cara mengutip $\quad$ : Pattisahusiwa, S., \& Diyanti, F. (2017). Pengungkapan Corporate Social \\ Responsibility, Struktur Corporate Governance dan Nilai Perusahaan. Jurnal \\ Ekonomi Modernisasi, 13(1), 25-36. \\ doi:http://dx.doi.org/10.21067/jem.v13i1.1763
}

Sejarah Artikel : Artikel diterima : Januari 2017; direvisi Februari 2017; diterima Maret 2017

\footnotetext{
Alamat korespondensi :

Fakultas Ekonomi dan Bisnis, Universitas Mulawarman

Jl. Tanah Grogot No. 1, Kampus Unmul Mount Kelua Samarinda, Samarinda Ulu,

Gn. Kelua, Samarinda, Kota Samarinda, Kalimantan Timur

ISSN 0216-373X (cetak)

E-mail:amahjais@gmail.com 


\section{Pendahuluan}

Perkembangan ekonomi yang begitu pesat dan persaingan yang begitu ketat memberikan tekanan bagi perluasan bisnis perusahaan. Hal ini berdampak kepada lingkungan karena tingkat konsumsi masyarakat terhadap sumber daya alam yang semakin meningkat. Dampak negatif ini semakin terlihat dengan semakin banyaknya kerusakan lingkungan yang mempengaruhi kehidupan masyarakat. Upaya yang dilakukan untuk meningkatkan nilai perusahaan dengan memanfaatkan sumber daya sekitar pada kenyataannya sering tidak sejalan dengan upaya untuk menjaga keberlangsungan lingkungan sumber daya tersebut berada. Oleh karena itu, merupakan hal yang penting bagi perusahaan untuk menjaga lingkungan sekitar perusahaan.

Adeneye dan Ahmed

menjelaskan bahwa corporate social responsibility memberikan pemahaman bahwa perusahaan memiliki kemampuan dan rasa tanggung jawab terhadap pertumbuhan dan perkembangan lingkungan sekitar perusahaan tersebut beroperasi. Hal ini berarti bahwa perusahaan memberikan pelayanan jasa secara sukarela kepada masyarakat sehingga berdampak secara langsung terhadap nilai perusahaan di masyarakat.

Struktur corporate governance menjaga keseimbangan antara tujuan ekonomi dengan tujuan sosial maupun tujuan individu dengan tujuan masyarakat. Struktur corporate governance juga dikembangkan lebih lanjut untuk permasalahan etika, akuntabilitas, pengungkapan dan pelaporan (Gill, 2008). adanya beberapa bentuk dari struktur corporate governance memiliki peran dalam mengawasi serta mengendalikan keputusan manajemen dan aktivitas perusahaan yang berdampak pada lingkungan termasuk masyarakat sekitar. Hal ini menjelaskan hubungan antara struktur corporate governance dan corporate social responsibility dengan nilai perusahaan (Habbash, 2016).

Penelitian ini menguji pengaruh pengungkapan corporate social responsibility dan struktur corporate governance yang diproksikan dengan dewan komisaris independen terhadap nilai perusahaan. Nilai perusahaan dipilih karena adanya anggapan bahwa setiap kebijakan dan tindakan yang diambil perusahaan berpengaruh terhadap nilai perusahaan.

Penelitian ini memiliki perbedaan dengan beberapa penelitian sebelumnya karena berfokus pada praktik corporate social responsibility pada perusahaan pertambangan di Indonesia yang diatur oleh UndangUndang No 32 tahun 2009 yang mengatur tentang Perlindungan dan Pengelolaan Lingkungan Hidup. Perusahaan pertambangan selama ini selalu menjadi sorotan utama ketika membahas tentang corporate social responsibility karena masih banyak perusahaan pertambangan yang merugikan lingkungan. Salah satu contoh adalah praktik pertambangan di kota Samarinda, dimana jumlah tambang yang cukup banyak menurut data Pemerintah, telah memaksa desa-desa dan sekolah untuk menjauhi longsoran lumpur yang beracun dan sumber-sumber air yang tercemar (Suryawan, 2013). Pada tingkat kepatuhan, perusahaan pertambangan juga menarik untuk diamati dalam menjaga lingkungan sekitar dengan menggunakan variabel struktur corporate governance yang diproksikan dengan dewan komisaris independen sebagai mekanisme internal pengawasan yang dapat meningkatkan nilai perusahaan.

Variabel pengungkapan corporate social responsibility dan struktur corporate governance terhadap nilai perusahaan dipilih karena 
adanya ketidakkonsistenan hasil dari beberapa penelitian sebelumnya. Hasil penelitian dari Dahlia dan Veronica (2008) serta Byus et al. (2010) menunjukkan bahwa corporate social responsibility berpengaruh terhadap nilai perusahaan. Kegiatan corporate social responsibility memiliki pengaruh positif yang tercermin dalam peningkatan profitabilitas perusahaan.

Kepedulian terhadap sosial dan lingkungan sekitar akan memberikan dampak kepada produk yang dihasilkan sehingga dapat diterima publik dengan baik dan meningkatnya penjualan. Adanya peningkatan penjualan akan berdampak pada nilai perusahaan. Hasil ini berbeda dengan penelitian dari Crisostomo et al. (2011) yang meneliti pengaruh dari corporate social responsibility terhadap nilai perusahaan dan kinerja perusahaan di negara Brazil. Hasil penelitian menunjukkan bahwa corporate social responsibility berpengaruh negatif terhadap nilai perusahaan sementara corporate social responsibility memiliki pengaruh netral terhadap kinerja perusahaan. Margolis dan Walsh (2003) menemukan bahwa corporate social responsibility tidak memiliki kontribusi terhadap nilai perusahaan karena investor lebih berorientasi kepada kinerja jangka pendek.

Weisbach (1988) memberikan bukti empiris bahwa jumlah dewan komisaris yang berasal dari luar perusahaan dapat memperkuat corporate governance pada perusahaan tersebut. Hal ini berdampak pada nilai perusahan yang semakin meningkat. Dahya dan McConnell (2007) menemukan bahwa perusahaan dengan jumlah proporsi dewan komisaris independen yang lebih banyak akan memiliki nilai perusahaan yang lebih tinggi. Hasil penelitian ini bertentangan dengan penelitian sebelumnya, dimana Park dan Shin (2003) serta Singh dan Davidson
(2003) dalam Hussein dan Venkatram (2013) tidak menemukan pengaruh yang signifikan antara struktur corporate governance khususnya komposisi dewan komisaris dengan nilai perusahaan.

Berdasarkan latar belakang tersebut, maka tujuan penelitian ini adalah untuk mengetahui: (1) pengaruh pengungkapan corporate social responsibility terhadap nilai perusahaan; (2) pengaruh struktur corporate governance yang diproksikan dengan keberadaan dewan komisaris independen terhadap nilai perusahaan.

\section{Tinjauan Pustaka}

\section{Agency Theory}

Jensen dan Meckling (1976) menjelaskan bahwa dalam agency theory, perspektif hubungan Manajer (agency) merupakan dasar untuk memahami corporate governance. Masalah yang dihadapi dalam perusahaan yaitu pemilik (the principal) tidak memainkan peran aktif dalam manajemen. Pemilik perusahaan mendelegasikan wewenang dan tanggung jawab kepada pihak manajemen untuk bekerja atas nama kepentingan pemilik perusahaan. Pendelegasian wewenang membuat manajemen mengambil strategi, taktik dan keputusan operasional yang dapat menguntungkan kepentingan mereka, sehingga dapat memicu konflik kepentingan. Di satu sisi, pemilik menginginkan manajer untuk bekerja keras sehingga dapat memaksimalkan keuntungan pemilik, namun di sisi lainnya, manajer juga ingin memaksimalkan keuntungan bagi diri sendiri.

\section{Stakeholder Theory}

Stakeholder theory merupakan penghubung bagi masalah etika dan strategi perusahaan. Tujuan utama perusahaan adalah mendapatkan keuntungan yang 
sebesar-besarnya bagi pemiliknya, namun hal ini dimaksudkan bahwa perusahaan tidak hanya beroperasi untuk kepentingannya saja, tetapi juga untuk kepentingan para stakeholder. Beberapa teori stakeholder berpendapat bahwa dengan mengatur perusahaan khususnya dalam menjaga hubungan baik dengan stakeholder akan berdampak baik bagi nilai perusahaan tersebut (Margolish dan Walsh, 2003).

Suatu kasus bisnis yang berkaitan dengan corporate social responsibility berpendapat bahwa ada beberapa alasan yang sah untuk sebuah perusahaan harus berinvestasi di kegiatan yang berkaitan dengan corporate social responsibility. Dari sudut pandang ekonomi, terdapat teori yang logis dan bukti empiris yang menjamin bahwa kegiatan yang berhubungan dengan tanggung jawab sosial dapat menurunkan biaya dan risiko dari perusahaan tersebut, memberikan keuntungan yang kompetitif bagi perusahaan, meningkatkan reputasi dan legitimasi, dan juga menciptakan sinergi (Salazar dan Husted, 2008)

\section{Nilai Perusahaan}

Nilai perusahaan yang semakin tinggi akan diikuti dengan semakin tingginya harga saham. Nilai perusahaan yang tinggi menjadi keinginan para pemilik perusahaan, sebab dengan nilai yang tinggi menunjukkan kemakmuran pemegang saham juga tinggi. Kekayaan pemegang saham dan perusahaan dipresentasikan oleh harga pasar dari saham yang merupakan cerminan dari keputusan investasi, pendanaan (financing) dan manajemen aset (Hermuningsih, 2012).

$$
\text { Brigham dan Houston (1999) }
$$

mendefinisikan nilai perusahaan sebagai nilai pasar yang dihasilkan manajemen dan organisasi perusahaan yang menggambarkan bahwa perusahaan tersebut akan terus tumbuh dan berkembang.
Beberapa penelitian memberikan pengukuran yang berbeda sebagai proksi dari nilai perusahaan. Sebagian besar peneliti menggunakan Tobin's Q sebagai proksi untuk penelitian yang dilakukan.

\section{Corporate Social Responsibility}

Prastowo dan Huda

menjelaskan bahwa corporate social responsibility merupakan tanggungjawab organisasi sebagai dampak dari suatu keputusan dan kegiatan kemasyarakatan dan lingkungan, melalui perilaku transparan dan etis yang memberikan kontribusi untuk pembangunan berkelanjutan, kesehatan dan kesejahteraan masyarakat; memperhitungkan harapan para pemangku kepentingan; sesuai dengan hukum yang berlaku dan konsisten dengan norma-norma internasional perilaku dan terintegrasi di seluruh organisasi dan dipraktekkan dalam suatu hubungan. Selanjutnya dijelaskan bahwa Siallagan dan Machfoedz (2006) menjelaskan bahwa tujuan utama perusahaan adalah memaksimalkan nilai perusahaan.

Berdasarkan definisi tersebut dapat dilihat bahwa pentingnya kesadaran dalam pengungkapan corporate social responsibility oleh perusahaan. Tujuan dari adanya pengungkapan corporate social responsibility yaitu sebagai wujud tanggung jawab atau komitmen yang dilakukan oleh perusahaan atas dampak-dampak lingkungan yang ditimbulkan dari aktivitas bisnisnya. corporate social responsibility juga dapat diartikan sebagai suatu bentuk kepedulian sosial sebuah perusahaan untuk melayani kepentingan organisasi maupun kepentingan publik eksternal.

\section{Struktur Corporate Governance}

Corporate governance (CG) merupakan mekanisme yang saling menyeimbangkan antara tindakan maupun pilihan manajer 
dengan kepentingan shareholders (Susanti, 2011). Penelitian mengenai corporate governance telah banyak yang dapat mengidentifikasikan berbagai macam mekanisme untuk memastikan bahwa team manajemen bertindak yang terbaik untuk mewakili kepentingan para pemegang saham. Mekanisme ini terbagi atas mekanisme internal dan mekanisme eksternal. Mekanisme internal antara lain: dewan direksi, kepemilikan manajemen dan kompensasi eksekutif. Mekanisme eksternal antara lain: kepemilikan institusional dan the level of debt financing (Barnhart and Rosentein, 1998).

Struktur corporate governance lainnya adalah dewan komisaris independen. Struktur Puncak sistem operasional internal perusahaan dipegang oleh dewan komisaris yang mempunyai peranan penting terhadap pengawasan operasional perusahaan. Dewan komisaris memegang kendali dalam menentukan keputusan dan kebijakan yang akan dilaksanakan perusahaan termasuk kebijakan mengenai CSR. Keberadaan dewan komisaris independen diharapkan dapat mempengaruhi perusahaan untuk melaksanakan dan mengungkapkan CSR dengan lebih baik karena dewan komisaris independen mendapat tanggungjawab besar untuk bertindak independen demi menjaga kepentingan pemegang saham (Purrbopangestu dan Subowo, 2014).

\section{Pengaruh Pengungkapan Corporate Social Responsibility terhadap Nilai Perusahaan}

Agency theory menjelaskan bahwa terjadi konflik kepentingan antara pihak manajemen dengan pemilik karena adanya perbedaan kepentingan dimana setiap pihak ingin memaksimalkan keuntungannya masing-masing.

Hal ini juga berkaitan erat dengan stakeholder theory yang menyatakan bahwa tujuan utama perusahaan adalah mendapatkan keuntungan yang sebesarbesarnya bagi Pemiliknya, namun hal ini dimaksudkan bahwa perusahaan tidak hanya beroperasi untuk kepentingannya saja, tetapi juga untuk kepentingan para stakeholder. Stakeholder theory sejalan dengan corporate social responsibility karena perusahaan harus memiliki perilaku tanggungjawab diantara dua pemilik, yaitu baik dengan para pemegang saham maupun dengan masyarakat sekitar (Harrison dan Wicks, 2013).

Corporate social responsibility berdampak secara langsung kepada nilai perusahaan di masyarakat karena perusahaan yang memiliki orientasi untuk tetap menjaga dan melindungi lingkungan sekitar akan membuat nama perusahaan menjadi lebih baik dan secara langsung berdampak pada peningkatan nilai perusahaan.

Hasil penelitian dari Dahlia dan Veronica (2008) serta Byus et al. (2010) menunjukkan bahwa corporate social responsibility berpengaruh terhadap nilai perusahaan. Kegiatan corporate social responsibility memiliki pengaruh positif yang tercermin dalam peningkatan profitabilitas perusahaan.

Kepedulian terhadap sosial dan lingkungan sekitar memberikan dampak kepada produk yang dihasilkan sehingga dapat diterima publik dengan baik dan meningkatnya penjualan. Adanya peningkatan penjualan berdampak pada nilai perusahaan. Berdasarkan uraian tersebut, maka hipotesis sebagai berikut: 
$\mathrm{H}_{1}$ : Pengungkapan corporate social responsibility berpengaruh terhadap nilai perusahaan

\section{Pengaruh Struktur Corporate}

\section{Governance terhadap Nilai Perusahaan}

Corporate Governance (CG) secara umum adalah seperangkat mekanisme yang saling menyeimbangkan antara tindakan maupun pilihan manajer dengan kepentingan shareholders (Susanti, 2011). Hal ini sesuai dengan agency theory yang menjelaskan hubungan antara pihak principal dan pihak agent. Menurut agency theory, perbedaan kepentingan antara pihak principal dan pihak agent dapat menimbulkan asimetri informasi. Oleh karena itu, corporate governance memegang peranan penting untuk mengatasi masalah asimetri informasi tersebut.

Struktur Corporate Governance dalam penelitian ini diproksikan dengan keberadaan dewan komisaris independen. Keberadaaan Dewan Komisaris independen dalam Dewan Komisaris merupakan salah satu indikator adanya independensi dari Dewan yang ada dalam Perusahaan. Kehadiran Dewan Komisaris Independen dapat meningkatkan kualitas pengawasan dalam perusahaan serta mengendalikan keputusan manajemen dan aktivitas perusahaan yang berdampak pada internal perusahaan, seperti dalam penyusunan laporan keuangan yang berkualitas.Adanya hasil output berupa laporan keuangan yang berkualitas dan berkurangnya asimetri informasi antara agent dan principalakan dinilai baik oleh pihak-pihak yang berkepentingan, karena dianggap perusahaan memiliki kinerja yang baik. Hal ini dapat meningkatkan nilai perusahaan di mata investor. Weisbach (1988), Muryati dan Suardhika (2014), serta Dahya dan McConnell (2007) menemukan bahwa perusahaan dengan jumlah proporsi dewan komisaris independen yang lebih banyak akan memiliki nilai perusahaan yang lebih tinggi. Berdasarkan uraian tersebut, maka dapat ditarik hipotesis sebagai berikut:

$\mathrm{H}_{2}$ : Struktur Corporate Governance yang diproksikan dengan keberadaan dewan komisaris independen berpengaruh terhadap nilai perusahaan

\section{Metode}

Variabel dependen dalam penelitian ini adalah nilai perusahaan. Brigham (1999) mendefinisikan nilai perusahaan sebagai nilai pasar yang dihasilkan manajemen dan organisasi perusahaan yang menggambarkan bahwa perusahaan tersebut akan terus tumbuh dan berkembang. Nilai perusahaan dalam penelitian ini diukur menggunakan Tobin's Q.

Variabel independen dalam penelitian ini ada 2 (dua) variabel yaitu pengungkapan Corporate Social Responsibility dan Struktur Corporate Governance. Variabel pertama yaitu pengungkapan Corporate social responsibility akan dihitung dengan menggunakan Corporate Social Disclosure Index (CSDI), indikatornya mengacu pada GRI (Global Reporting Initiatives) dengan komponen pengungkapan yang terdiri atas: ekonomi, lingkungan dan sosial sebagai dasar Sustainability Reporting.

Variabel kedua yaitu struktur Corporate Governance yang diproksikan dengan keberadaan dewan komisaris independen. Pengertian dewan komisaris independen menurut Komite Nasional Kebijakan Governance (2011) adalah Dewan Komisaris yang tidak berasal dari pihak terafiliasi, yang dimaksud dengan terafiliasi adalah pihak yang mempunyai hubungan bisnis dan kekeluargaan dengan pemegang saham pengendali, anggota direksi dan dewan komisaris lain, serta dengan perusahaan itu sendiri. Keberadaan dewan 
komisaris independen diukur dengan cara menghitung persentase proporsi jumlah dewan komisaris independen dibandingkan dengan total anggota komisaris secara keseluruhan. Populasi dalam penelitian ini adalah perusahaan-perusahaan sektor pertambangan yang terdaftar di Bursa Efek
Indonesia berturut-turut selama tahun 2014 s./d 2015 yang berjumlah 41 perusahaan. Pemilihan sampel dilakukan dengan menggunakan metode purposive sampling yaitu metode pengambilan sampel sesuai dengan kriteria yang telah ditentukan.

\section{Tabel 1. Seleksi Sampel Penelitian}

\begin{tabular}{lc}
\hline \multicolumn{1}{c}{ Keterangan } & Jumlah \\
\hline Perusahaan sektor pertambangan batu bara yang terdaftar di Bursa Efek & 41 \\
Indonesia berturut-turut selama 2014 s/d 2015 & \\
\hline Perusahaan mengalami kerugian selama periode pengamatan & $(8)$ \\
\hline Data yang dibutuhkan tidak tersedia dengan lengkap & $(15)$ \\
\hline Jumlah Objek yang Diteliti & 18 \\
\hline
\end{tabular}

Berdasarkan tabel diatas, maka jumlah objek yang diteliti adalah 18 perusahaan. Periode penelitian yang digunakan adalah selama 2 (dua) tahun, sehingga total sampel yang digunakan dalam penelitian ini adalah 36 sampel.

Tehnik analisis mengunakan tehnik analisis kuantitatif. Alat analisis yang digunakan dalam penelitian ini adalah Analisis Regresi Linier Berganda. Persamaan Regresi yang digunakan dalam penelitian ini adalah sebagai berikut:

$$
\text { Tobins' } \mathrm{Q}=\alpha+\beta_{1} \mathrm{CSRD}+\beta_{2} \mathrm{KI}+\epsilon
$$

Tahap analisis data dimulai dengan melakukan Uji Asumsi Klasik, yang terdiri dari uji Normalitas, uji Multikolonearitas, uji Autokolerasi dan uji Heteroskedastisitas. Tahap berikutnya yaitu melakukan Uji Statistik F (Uji Kelayakan model) untuk menunjukkan apakah semua variabel independen mampu menjelaskan variabel dependen, sehingga model layak untuk digunakan. Tahap terakhir dilakukan Pengujian Hipotesis (Uji t) untuk menunjukkan seberapa jauh pengaruh variabel independen terhadap variabel dependen.

\section{Hasil dan Pembahasan}

\section{Hasil Uji Asumsi Klasik}

Hasil uji normalitas dengan menggunakan uji Kolmogorov-Smirnov adalah sebagai berikut:

\section{Tabel 2. Hasil Uji Normalitas Data}

\begin{tabular}{lr}
\hline & $\begin{array}{r}\text { Unstandardized } \\
\text { Residual }\end{array}$ \\
\hline $\mathrm{N}$ & 36 \\
Mean & 0.0000 \\
Parameters Std. & 0.26878619 \\
deviation & .120 \\
Absolute & .100 \\
Difference & -.130 \\
PositiveNegative & .423 \\
Kolmogorov Smirnov & .216 \\
Z & \\
Asymp. Sig (2-tailed) & \\
\hline Sumber: Data diolah &
\end{tabular}


Jurnal Ekonomi Modernisasi, 13 (1) 2017, 25-36

Berdasarkan pada tabel 2, hasil uji normalitas terhadap data residual menunjukkan bahwa besarnya Asymp. Sig (2tailed) sebesar 0,216 diatas tingkat signifikansi 0,05. Hasil pengujian ini menunjukkan bahwa model regresi telah memenuhi standar normalitas.

Hasil uji Multikollinearitas dapat dilihat berikut ini:

Tabel 3. Hasil Uji Multikollinearitas

\begin{tabular}{lcc}
\hline \multirow{2}{*}{ Model } & \multicolumn{2}{c}{ Collinearity } \\
& \multicolumn{2}{c}{ Statistics } \\
\cline { 2 - 3 } & Tolerance & VIF \\
\hline CSRD & .861 & 1.162 \\
\hline KI & .943 & 1.035 \\
\hline
\end{tabular}

Sumber: Data diolah

Nilai tolerance pada tabel tersebut menunjukkan bahwa tidak ada variabel independen yang memiliki nilai tolerance kurang dari 0,10 (10\%). Nilai VIF juga menunjukkan bahwa tidak ada variabel independen yang memiliki nilai VIF lebih dari 10. Oleh karena itu, dapat disimpulkan bahwa tidak ada multikolinearitas antara variabel independen dalam model regresi.

Hasil uji autokorelasi dapat dilihat pada tabel berikut:

Tabel 4. Hasil Uji Autokorealasi

\begin{tabular}{lrrr}
\hline Model & $\begin{array}{c}\text { Adjusted } \\
\text { R Square }\end{array}$ & $\begin{array}{c}\text { Std Error } \\
\text { of the } \\
\text { Estimate }\end{array}$ & $\begin{array}{c}\text { Durbin } \\
\text { Watson }\end{array}$ \\
\hline 1 & .042 & 2.26173 & 1.6592 \\
\hline
\end{tabular}

Sumber: Data diolah

Berdasarkan pada tabel 4, hasil uji autokorelasi dapat dinilai bahwa nilai
Durbin Watson (DW) sebesar 1,659. Nilai ini akan dibandingkan dengan nilai tabel dengan menggunakan signifikansi 0,05 dengan jumlah sampel 36 perusahaan. Sedangkan dari tabel dw dengan signifikansi 0,05 dan jumlah data (n) $=36$, maka diperoleh nilai 4-du sebesar 2,3568 dan du sebesar 1,6432. Nilai dw sebesar 1,6592 lebih besar dari du yaitu 1,6432 dan lebih kecil dari nilai 4-du sebesar 2,3568, maka menunjukkan bahwa model regresi tersebut tidak terjadi autokorelasi.

\section{Hasil Uji Kelayakan Model}

Hasil uji kelayakan model dapat dilihat pada tabel berikut ini:

\section{Tabel 5. Hasil Uji F}

\begin{tabular}{lrrcc}
\hline \multicolumn{1}{c}{ Model } & Df & $\begin{array}{r}\text { Mean } \\
\text { Square }\end{array}$ & F & Sig \\
\hline Regression & 2 & 12,425 & 2.841 & .030 \\
Residual & 33 & 5,529 & & \\
Total & 35 & & & \\
\hline
\end{tabular}

Sumber: Data diolah

Hasil uji pada tabel tersebut menunjukkan bahwa nilai signifikansi $F$ lebih kecil daripada nilai $\alpha(\alpha=0,05)$, sehingga dapat disimpulkan bahwa semua variabel independen mampu menjelaskan variabel dependen atau dengan kata lain model layak untuk digunakan.

\section{Hasil Pengujian Hipotesis}

Uji Statistik $t$ pada dasarnya menunjukkan pengaruh satu variabel independen secara individual dalam menerangkan variabel dependen. Hasil pengujian dapat dilihat pada tabel berikut : 
Salmah Pattisahusiwa \& Ferry Diyanti / Pengungkapan Corporate Social ....

Tabel 6. Hasil Uji t

\begin{tabular}{|c|c|c|c|c|c|}
\hline \multirow{2}{*}{ Model } & \multicolumn{2}{|c|}{$\begin{array}{c}\text { Unstandardized } \\
\text { Coefficients }\end{array}$} & \multirow{2}{*}{$\begin{array}{c}\text { Standardized } \\
\text { Coefficients }\end{array}$} & \multirow{2}{*}{$\mathrm{t}$} & \multirow{2}{*}{ Sig. } \\
\hline & $\mathrm{B}$ & Std. Error & & & \\
\hline (Constant) & .653 & .234 & & 14.623 & .000 \\
\hline CSRD & .746 & .051 & .596 & 3.808 & .023 \\
\hline $\mathrm{KI}$ & .672 & .074 & .386 & 2.169 & .034 \\
\hline
\end{tabular}

Sumber: Data Diolah

Berdasarkan tabel tersebut, dapat dilihat bahwa pengungkapan corporate social responsibility dan struktur corporate governance yang diproksikan dengan keberadaan dewan komisaris independen memiliki nilai signifikansi t dibawah nilai $\alpha(\alpha=0,05)$, sehingga dapat disimpulkan bahwa pengungkapan corporate social responsibility dan struktur corporate governance yang diproksikan dengan keberadaan dewan komisaris independen berpengaruh terhadap nilai perusahaan.

Hasil pengujian hipotesis pertama menunjukkan bahwa pengungkapan corporate social responsibility berpengaruh terhadap nilai perusahaan. Hasil penelitian ini konsisten dengan penelitian dari Dahlia dan Veronica (2008) serta Byus et al. (2010) dan mendukung stakeholder theory yang menjelaskan bahwa perusahaan seharusnya bukan hanya memperhatikan kepentingan sendiri, namun juga memberikan manfaat bagi stakeholder yang berkepentingan terhadap perusahaan tersebut. Perusahaan pertambangan di Indonesia sudah mulai melakukan corporate social responsibility karena menyadari bahwa keberadaan perusahaan tidak dapat dilepaskan dari kehidupan sosial, lingkungan dan masyarakat sekitar. Kepatuhan perusahaan dalam melakukan corporate social responsibility juga tidak terlepas dari peranan Pemerintah yang mulai secara tegas menerapkan Undang-Undang No 32 tahun 2009 tentang Perlindungan dan
Pengelolaan Lingkungan Hidup. UndangUndang ini memberikan rambu-rambu yang mampu mengatur perusahaan untuk melakukan corporate social responsibility dengan lebih baik, khususnya terhadap lingkungan. Di sisi lain, penerapan dan dan pengungkapan corporate social responsibility bagi perusahaan akan mendapatkan keuntungan berupa image perusahaan yang semakin baik dan pada akhirnya akan meningkatkan nilai perusahaan secara keseluruhan di mata para stakeholder khususnya investor. Perusahaan dapat meraih dukungan yang berkelanjutan dan menikmati pertumbuhan pangsa pasar, penjualan serta laba yang terus meningkat.

Hasil pengujian hipotesis kedua menunjukkan bahwa struktur corporate governance yang diproksikan dengan keberadaan dewan komisaris independen berpengaruh terhadap nilai perusahaan. Hasil penelitian ini konsisten dengan penelitian dari Weisbach (1988), Muryati dan Suardhika (2014) serta Dahya dan McConnell (2007) dan mendukung agency theory bahwa memang terdapat perbedaan kepentingan antara agent dan principal sehingga dapat memunculkan asimetri informasi, namun hal ini dapat dikurangi dengan adanya peranan dari dewan komisaris independen yang mampu menjalankan fungsi pengawasan terhadap semua kebijakan dan kegiatan yang dilakukan oleh pihak manajemen. Keberadaan dewan komisaris independen 
Jurnal Ekonomi Modernisasi, 13 (1) 2017, 25-36

akan memberikan kontribusi yang cukup besar dan efektif terutama dalam proses penyusunan laporan keuangan yang berkualitas sehingga berdampak pada peningkatan nilai perusahaan di mata para investor.

\section{Simpulan}

Berdasarkan hasil penelitian dapat disimpulkan bahwa pengungkapan corporate social responsibility dan struktur corporate governance yang diproksikan dengan keberadaan dewan komisaris independen berpengaruh terhadap nilai perusahaan. Adanya pengungkapan corporate social responsibility dan keberadaan dewan komisaris independen dapat meningkatkan nilai perusahan di mata stakeholder khususnya para investor.

Adapun keterbatasan pada penelitian ini adalah bahwa sampel yang digunakan dalam penelitian ini terbatas pada sampel perusahaan pertambangan dengan periode penelitian selama 2 (dua) tahun, sehingga untuk penelitian berikutnya diharapkan mempertimbangkan jenis perusahaan lain yang dapat dijadikan sampel, seperti: industri kimia yang juga memiliki dampak besar terhadap lingkungan, serta memperpanjang periode penelitian untuk mendapatkan hasil yang lebih akurat.

Variabel independen yang digunakan dalam penelitian ini hanya terbatas pada pengungkapan Corporate Social Responsibility dan struktur Corporate Governance yang diproksikan dengan keberadaan dewan komisaris independen, sehingga untuk penelitian berikutnya diharapkan dapat mempertimbangkan variabel lainnya, seperti: komite audit, rasio keuangan dan ukuran perusahaan.

\section{Daftar Pustaka}

Adeneye, Babatunde, Ahmed, Maryam. (2015). Corporate Social Responsibility and Company Performance. Journal of Business Studies Quaterly Vol.7 No.1

Barnhart, Scott W, Stuart, Rosenstein. (2008). Board Composition, Managerial Ownership and Firm Performance: An Empirical Analysis. The Financial Review. Vol 33: 1-16

Byus, K., D. Deis, B. Ouyang. (2010). Doing Well by Doing Good: Corporate Social Responsibility and Profitability. SAM Advanced Management Journal. Vol. 3, No.1: 44-55

Brigham, E.F, J.F Houston. (1999). Majamenen Keuangan. Jakarta : Erlangga

Crisostomo, V. L, F. S. Freire, F. C. Vasconcellos. (2007). Corporate Social Responsibility, Firm Value and Financial Performance in Brazil. Social Responsibility Journal, Vol. 7, No. 2: 295309.

Dahya, Jay, McConnell , John J. (2007). Board Composition, Corporate Performance, and the Cadbury Committee Recommendation, Journal of Financial and Quantitative Analysis, Vol. 42: 535-564

Dahlia, Veronica. (2008). Pengaruh Corporate Social Responsibility terhadap Kinerja Perusahaan (Studi Empiris Pada Perusahaan yang Tercatat Di Bursa Efek Indonesia pada Tahun 2005 dan 2006). Jurnal FE UNS. Semarang

Gill, A. (2008). Corporate Governance as Social Responsibility: A Research Agenda. Berkeley Journal of International Law. Vol.26 No. 2: 452-478

Habbash, Murya. (2016). Corporate Governance and Corporate Social Responsibility Disclosure: Evidence From Saudi Arabia. Journal of Economic 
Salmah Pattisahusiwa \& Ferry Diyanti / Pengungkapan Corporate Social ....

and Social Development. Vol 3 No 1: 87103

Harrison, Jeffrey S, Wicks, Andrew C. (2013). Stakeholder Theory, Value and Firm Performance. Business Ethics Quaterly. Vol. 23 No. 1: 97-124

Hermuningsih, Sri. (2012). Pengaruh Profitabilitas, Size terhadap Nilai Perusahaan dengan Struktur Modal sebagai Variabel Intervening. Jurnal Siasat Bisnis. Vol.16 No. 2: 232-242

Hussein, Salih Kheiralla, Venkatram, Rengan. (2013). Corporate Governance and Firm's Value: An Empirical Analysis of Agri-input Firms in India. International Journal of Commerce, Business and Management. Vol. 2 No.6: 353-362

Jensen, MC. W.H. Meckling. (1976). Theory of The Firm: Managerial Behavior, Agency Cost and Ownership Structure. Journal of Financial Economics, Vol 3: 305-360

Komite Nasional Kebijakan Governance. (2011). Pedoman Penerapan Manajemen Risiko Berbasis Governance. Jakarta

Mangantar, Maryam, Ali, Muhammad. (2015). An Analysis of the Influence of Ownership Structure, Invesment, Liquidity and Risk to Firm Value: Evidence from Indonesia. American Journal of Economics and Business Administration. Vol. 7 No. 4: 166-176

Margolis, J.D, Walsh, J.P. (2003). Misery Loves Companies: Rethinking Social Initiatives by Business. Administrative Science Quarterly. Vol 48 No. 5: 268-305

Moeljadi, Supriyati, Triningsih Sri. (2014). Factors Affecting Firm Value: Theoretical Study on Public Manufacturing Firms in Indonesia. South East Asia Journal of Contemporary Business, Economic and Law. Vol. 5 No. 2: 6-15
Muryati, Ni Nyoman Tri Sariri, Suardhika, I Made Sadha. (2014). Pengaruh Corporate Governance terhadap Nilai Perusahaan. E-jurnal Akuntansi. Universitas Udayana. Vol. 9 No. 2: 411-429

Purbopangestu, Hary Wisnu, Subowo. (2014). Pengaruh Good Corporate Governance terhadap Nilai Perusahaan dengan Corporate Social Responsibility sebagai Variabel Intervening. Accounting Analysis Journal. Vol. 3 No.3: 321-333

Prastowo, Joko, Huda, Miftachul. (2011). Corporate Social Responsibility: Kunci Meraih Kemuliaan Bisnis. Yogyakarta: Samudra Biru

Rustiarini, Ni Wayan. (2012). Corporate Governance, Konsentrasi Kepemilikan dan Pengungkapan Enterprise Risk Management. Jurnal Manajemen Keuangan Dan Akuntabilitas.Vol. 11 No. 2: 279 - 298

Salazar, José \& Husted, Bryan W. (2008). Measuring Corporate Social Performance. Proceedings of the International Association for Business and Society. 19, 149-161.

Siallagan, Hamonagan \& Mas'ud Machfoedz. (2006). "Mekanisme Corporate Governance, Kualitas Laba dan Nilai Perusahaan". Simposium Nasional Akuntansi IX, Padang, 23-26 Agustus.

Susanti, Serli Ike Ari. (2011). Pengaruh Kualitas Corporate Governance, Kualitas Audit, dan Earnings Management Terhadap Kinerja Perusahaan. Jurnal Ekonomi dan Bisnis. Vol. 5 No.2: 145-161

Sudiyatno, Bambang, Puspitasari, Elen. (2010). Tobins'Q dan Altman Z-Score sebagai Indikator Pengukuran Kinerja Perusahaan. Kajian Akuntansi. Vol. 2 No. 1: 9-21 
Jurnal Ekonomi Modernisasi, 13 (1) 2017, 25-36

Suryawan, Zevanya. (2013). Eksploitasi Batu

Bara Rusak Kalimantan.

www.voaindonesia.com. Diakses pada

tanggal 2 April 2017

Undang-Undang No 32 tahun (2009).

Perlindungan dan Pengelolaan

Lingkungan Hidup

Weisbach, M. (1988). Outside Directors

And Ceo Turnover. Journal of Financial

Economics, 20. 431-460 